\title{
HAND SMOOTHITIZER, ANTISEPTIK PELEMBUT TANGAN UNTUK GENERASI TANGGAP PENYEBARAN KUMAN
}

\author{
Kris Haryanti* ${ }^{* 1}$, Wisnu Hidayat ${ }^{2}$, Afrina Kartika Putri ${ }^{3}$ \\ 1,2,3 Progam Studi Farmasi, STIKES Al Irsyad Al Islamiyyah Cilacap Indonesia \\ e-mail : ${ }^{1}$ Krisharyanti011@gmail.com ${ }^{2}$ wisnuhidayat108@ gmail.com ${ }^{3} \underline{\text { afrinakartika426@ gmail.com }}$
}

\begin{abstract}
ABSTRAK
Formulasi pembersih tangan secara tradisional mengandung etanol atau alkohol berantai pendek lainnya (60\%-70\%) sebagai bahan aktif. Namun, penggunaan alkohol sebagai produk hand sanitizer mudah menguap dan dapat menguap pada permukaan kulit sehingga aktivitas bakteri residual menjadi terbatas. Penelitian ini bertujuan untuk mengembangkan formulasi hand sanitizer yang rendah kadar alkohol, dengan menggunakan ekstrak dari bahan alami sebagai bahan aktif antibakteri. Bahan alamai yang digunakan yaitu limbah kulit buah jeruk nipis dan lidah buaya. Hasil penelitian menunjukan ekstrak kulit jeruk nipis dan lidah buaya dapat menghambat aktivitas bakteri Staphylococcus aureus. Evaluasi sediaan hand sanitizer menunjukkan hasil yang baik pada uji organoleptis, pH, bobot jenis dan uji antibakteri terhadap bakteri Staphylococcus aureus.
\end{abstract}

Kata kunci: kulit jeruk nipis, lidah buaya dan hand sanitizer.

\begin{abstract}
Traditional hand sanitizer formulations contain ethanol or other short chain alcohol (60\% $70 \%$ ) as active ingedients. However, the use of alcohol as a hand sanitizer product is volatile and can evaporate on the skin's surface, limiting residual bacterial activity. This study aims to develop a low alcohol hand sanitizer formulation using extracts from natural ingedients as an antibacterial active ingedient. Natural ingedients used are lime peel and aloe vera. The results showed that the extract of lime peel and aloe vera can inhibit the activity of Staphylococcus aureus bacteria. Evaluation of hand sanitizer preparations showed good results on organoleptic tests, $\mathrm{pH}$, specific gavity and antibacterial tests against Staphylococcus aureus bacteria.
\end{abstract}

Keywords: Lime peel, Aloe vera and Hand Sanitizer.

\section{PENDAHULUAN}

Kebersihan merupakan hal yang sangat peting dalam kehidupan sehari-hari. Penerapan kebersihan yang paling penting yaitu praktik sanitasi. ${ }^{[1]}$ Pengertian sanitasi sesungguhnya ditujukan kepada kebersihan secara umum yang penyebabnya terletak pada faktor lingkungan. ${ }^{[2]}$ Dengan kondisi lingkungan yang bersih tentunya akan membuat tubuh menjadi sehat dan tidak mudah terserang penyakit. Terdapat banyak faktor yang mempengaruhi kesehatan salah satunya termasuk ke dalam kebersihan, seperti kebersihan lingkungan, kebersihan makanan dan kebersihan badan. Kebersihan badan merupakan kebersihan yang sangat penting, karena apabila tidak menjaga kebersihan terutama kebersihan badan, maka tidak menutup kemungkinan seseorang akan dengan mudah terserang penyakit. Masuknya penyakit ke dalam tubuh bisa melalui makanan, oleh karena itu penting sekali menjaga kebersihan tangan agar dapat meminimalisir masuknya kuman penyebab penyakit ke dalam tubuh. 
Pada umumnya hand sanitizer mempunyai kandungan alkohol yang tinggi. Alkohol, merupakan bahan aktif pada hand sanitizer yang dapat membunuh bakteri, virus dan jamur, namun penggunaan alkohol yang berlebihan dapat menyebabkan dehidrasi pada kulit sehingga kulit menjadi kering. Kebiasaan yang berhubungan dengan kebersihan perorangan yang penting dalam penularan kuman diare adalah mencuci tangan. ${ }^{[3]}$ Sebuah systematic review menunjukan bahwa mencuci tangan dapat mengurangi resiko penyakit diare. ${ }^{[4]}$ Mencuci tangan menjadi salah satu solusi untuk menjaga kebersihan tangan, selain mencuci tangan menggunakan sabun, penggunaan gel antiseptik juga dianggap lebih praktis. ${ }^{[5]}$ Beredarnya hand sanitizer atau pencuci tangan tanpa air telah memberikan banyak manfaat bagi para konsumen. Selain dapat membunuh kuman di tangan, hand sanitizer juga merupakan produk yang bersifat mobile sehingga dapat digunakan dimanapun dan kapanpun. Penggunaan alkohol sebagai produk hand sanitizer mudah menguap dan dapat menguap pada permukaan kulit sehingga aktivitas bakteri residual menjadi terbatas.

Oleh karena itu, perlu adanya terobosan baru untuk melakukan inovasi dari produk hand sanitizer yang telah beredar di pasaran. Hadirnya Hand Smoothitizer dapat menjadi solusi terhadap permasalahan yang telah dipaparkan. Oleh karenanya penulis membuat sebuah inovasi, yaitu Hand Smoothitizer yang di dalamnya mengandung jeruk nipis dan lidah buaya. Jeruk nipis dan lidah buaya selain berfungsi sebagai antiseptik juga dapat melembutkan tangan. Jeruk nipis atau Citrus aurantifolia merupakan bahan alam yang memiliki potensi aktivitas sebagai antiseptik. ${ }^{[6]}$ Kulit jeruk nipis memiliki kandungan flavonoid yang lebih tinggi daripada jus butiran daging buahnya. Zat-zat yang terkandung dalam kulit jeruk nipis mampu bekerja sebagai zat anti inflamasi, anti bakteri, anti mikroba anti virus, anti oksidan. ${ }^{[7]}$ Ekstrak kulit jeruk nipis dapat menghambat pertumbuhan bakteri Staphylococcus aureus. Semua bagian dari tanaman lidah buaya dapat dimanfaatkan, untuk perawatan tubuh ataupun untuk mengobati berbagai macam penyakit. ${ }^{[8]}$ Lidah buaya memiliki kemampuan sebagai antibakteri karena kandungan senyawa aktifnya. Lidah buaya mengandung saponin, amiloglikosida, tanin, fenol, flavonoid dan minyak atsiri yang berfungsi sebagai antimikroba. ${ }^{[9]}$ Keistimewaan lidah buaya terletak pada bagian gel nya yang mampu untuk meresap di dalam jaringan kulit, sehingga banyak menahan kehilangan cairan yang terlalu banyak dari dalam kulit. ${ }^{[10]}$ Berdasarkan hasil penelitian diketahui bahwa lidah buaya memiliki kemampuan dalam menghambat pertumbuhan bakteri Pseudomonas aeruginosa, Salmonella typhi dan Staphylococcus aureus. ${ }^{[1]}$ Selain itu, lidah buaya juga memiliki aktivitas antibakteri terhadap $B$. cereus, B. subtilis, $S$. aureus, $S$. pyogenesis, E. coli, $P$. aeruginosa, $K$. aneumoniae dan S. thyphi. ${ }^{[12]}$

\section{METODE PENELITIAN}

\subsection{Alat dan Bahan}

Alat yang digunakan pada penelitian ini yaitu seperangkat alat gelas kimia, blender, waterbath, autoclave, piknometer, kertas $\mathrm{pH}$, kertas saring botol spray. Bahan baku yang digunakan pada penelitian ini yaitu kulit jeruk nipis, lidah buaya, alkohol 70\%, metil paraben dan gliserin.

\subsection{Jalannya Penelitian}

\subsubsection{Pembuatan Ekstrak Kulit Jeruk Nipis Dan Lidah Buaya}

Limbah kulit jeruk nipis diperoleh dari warung makan di daerah Cilacap yang memang sangat melimpah dan tidak dimanfatkan sebagaimana mestinya. Limbah kulit jeruk nipis kemudian dibersihkan dan dikeringkan dengan oven pada suhu $50^{\circ} \mathrm{C}$ hingga kering dan kemudian dihaluskan. Serbuk kulit jeruk nipis kemudian di maserasi menggunakan alkohol 96\% selama 4x24 jam dan dilakukan pengadukan setiap hari secara periodik. Untuk menghasilkan sari kulit jeruk nipis, maserat disaring dan di evaporasi menggunakan waterbath hingga diperoleh ekstrak kental. Begitu pula dengan lidah buaya juga diperoleh dari warga 
sekitar yang banyak tersebar di wilayah cilacap, setelah di ambil dari batangnya tangkai lidah buaya kemudian dibersihkan, kemudian diambil bagian dagingnya saja dan dihaluskan untuk kemudian disaring dan di ambil sarinya saja.

\subsubsection{Sterilisasi Peralatan Uji}

Erlenmeyer, gelas beker, dan tabung reaksi ditutup area lubang menggunakan kapas steril selanjutnya dibungkus dengan kertas perkamen, dan disterilkan menggunakan autoclave dengan temperatur $121^{\circ} \mathrm{C}$ dan waktu 15 menit. Untuk alat seperti jarum ose disterilkan dengan cara pemanasan langsung yaitu memijarkan jarum ose dengan api bunsen.

\subsubsection{Pembuatan Hand Smoothitizer} berikut :

Pembuatan hand smoothitizer dengan formulasi yang terdapat pada tabel I sebagai

Tabel I. Rancangan Formula Penelitian

\begin{tabular}{lccc}
\hline \multicolumn{1}{c}{ Bahan } & \multicolumn{3}{c}{ Formula } \\
\hline & I & II & III \\
Ekstrak kulit jeruk & $15 \mathrm{~mL}$ & $10 \mathrm{~mL}$ & $15 \mathrm{~mL}$ \\
nipis & & & \\
Ekstrak lidah buaya & $15 \mathrm{~mL}$ & $15 \mathrm{~mL}$ & $10 \mathrm{~mL}$ \\
Gliserin & $1 \mathrm{~mL}$ & $1 \mathrm{~mL}$ & $1 \mathrm{~mL}$ \\
Metil paraben & $1 \mathrm{~g}$ & $1 \mathrm{~g}$ & $1 \mathrm{~g}$ \\
Alkohol 70\% & Ad 50 mL & Ad $50 \mathrm{~mL}$ & Ad 50 mL \\
\hline
\end{tabular}

\subsubsection{Evaluasi Sediaan}

a. Pengamatan Organoleptis

Pengamatan organoleptis merupakan evaluasi pengamatan menggunakan panca indera terhadap bentuk, bau, warna dan rasa dari suatu sediaan.

b. Uji pH

Uji $\mathrm{pH}$ bertujuan untuk mengetahui apakah sediaan yang dibuat memenuhi nilai $\mathrm{pH}$ yang sesuai $\mathrm{pH}$ kulit. Penentuan nilai $\mathrm{pH}$ dilakukan dengan menggunakan indicator $\mathrm{pH}$. Kertas $\mathrm{pH}$ dicelupkan ke dalam sediaan, setelah kertas $\mathrm{pH}$ tercelup dengan sempurna, angkat kertas $\mathrm{Ph}$ kemudian cocokan warna pada kemasan kertas $\mathrm{pH}$. Uji sifat fisik meliputi uji $\mathrm{pH}$, uji bobot jenis.

c. Uji Bobot Jenis

Uji bobot jenis bertujuan untuk mengetahui bobot jenis suatu sediaan.

d. Uji kesukaan

Uji kesukaan terhadap sediaan bertujuan untuk mengetahui formula sediaan yang disukai oleh responden. Uji kesukaan dilakukan terhadap 20 responden untuk mecoba menggunakan sediaan Hand Smoothitizer.

e. Uji aktivitas antibakteri sediaan Hand Smoothitizer terhadap bakteri S. Aureus.

Uji aktivitas antibakteri bertujuan untuk mengetahui kemampuan sediaan dalam menghambat bakteri $S$. aureus. Media yang digunakan dalam uji aktivitas antibakteri adalah nutrient agar (NA), penggunaan nutrien agar (NA) karena merupakan media yang umum digunakan untuk menumbuhkan bakteri. ${ }^{[13]}$ Pengujian antibakteri digunakan dengan cawan petri yang sudah berisi media NA. Diambil $100 \mu \mathrm{L}$ suspensi bakteri S. aureus dan dimasukkan pada permukaan media NA kemudian diratakan dengan alat ose hingga rata dan di diamkan 5-10 menit agar bakteri meresap pada media. Kertas saring yang telah 
dibasahi dengan ekstrak kulit jeruk nipis, ekstrak lidah buaya, spray blank (gliserin+alkohol 70\%+metil paraben) dan spray aktif (ekstrak kulit jeruk nipis+ekstrak lidah buaya+gliserin+alkohol $70 \%+$ metil paraben) dengan konsentrasi masing-masing $0,01 \%$, ditempelkan pada permukaan media NA, selanjutnya diinkubasi pada suhu $37^{\circ} \mathrm{C}$ selama 24 jam. Pembacaan hasil uji antibakteri dilakukan dengan cara mengamati ada tidaknya zona hambatan.

\subsection{Analisis Data}

Analisis data pada penelitian ini menggunakan uji kesukaan terhadap sediaan yang bertujuan untuk mengetahui formula yang disukai oleh responden. Uji kesukaan Hand Smoothitizer dilakukan pada 20 orang responden. Pengujian ini meliputi kesukaan terhadap kriteria bentuk, aroma/bau dan warna dari sediaan Hand Smoothitizer. Dari hasil penelitian dapat diketahui bahwa Formula III paling banyak disukai oleh responden. Dari hasil uji tersebut dapat diketahui bahwa sebanyak 20 responden menyukai bentuk sediaan yang dibuat yaitu bentuk spray, baik pada FI, FII dan FIII, bentuk sediaan spray lebih nyaman digunakan daripada bentuk sediaan gel karena lebih cepat kering setelah pemakaian. Pada FI, kriteria yang paling disukai responden yaitu pada kriteria bentuk sediaan, sedangkan untuk kriteria warna dan aroma, apabila dibandingkan dengan FII dan FII, kriteria warna dan aroma pada FI masih kurang disukai oleh responden hal ini berkaitan dengan hasil uji organoleptis, bahwa pada FI warna sediaan yaitu cokelat dan memiliki aroma khas lidah buaya sehingga formula ini kurang disukai oleh responden. FI mengandung jumLah ekstrak jeruk nipis dan lidah buaya yang lebih banyak dari FII dan FIII hal iniah yang menyebabkan sediaan FI memiliki warna cokelat dan aroma khas lidah buaya. Ekstrak jeruk nipis berbentuk kental dan berwarna cokelat, maka semakin banyak jumLah ekstrak jeruk nipis yang digunakan maka akan semakin keruh warna sediaan yang dihasilkan.

Pada FII, kriteria yang paling disukai oleh responden yaitu pada kriteria bentuk sediaan, sedangkan untuk kriteria warna dan aroma menunjukan hasil yang lebih baik dibandingkan dengan FI. Pada FII menunjukan hasil bahwa responden menyukai semua kriteria yang meliputi bentuk sediaan, warna dan aroma dari sediaan. Hal ini berkaitan dengan hasil uji organoleptis yang menunjukan bahwa pada FI warna sediaan yaitu kekuningan dan aroma khas alkohol. Hasil uji kesukaan dapat dilihat pada gambar 1 berikut :

\section{Gambar 1. Hasil Analisis Data}

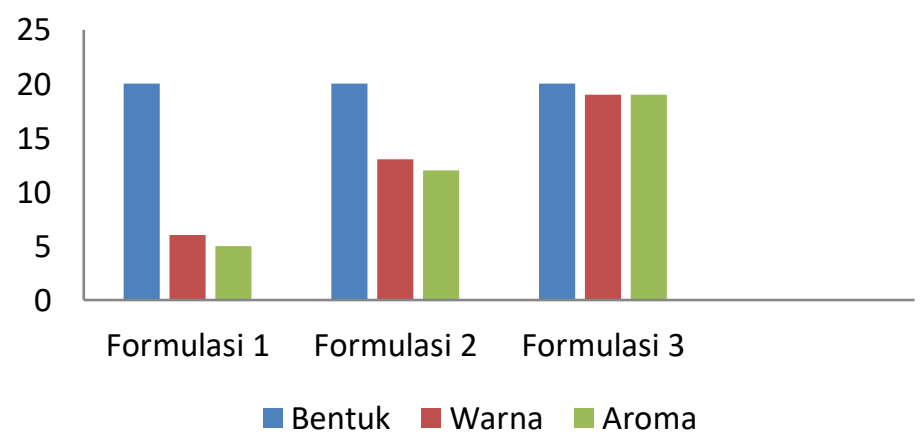

Jurnal Ilmiah Jophus Vol. 2, No. 2, Februari 2021 : 21-28 


\section{HASIL DAN PEMBAHASAN}

\subsection{Uji Organoleptis}

Uji organoleptis dilakukan untuk mengetahui bentuk, bau dan warna dari sediaan yang dibuat. Uji ini penting untuk dilakukan, karena uji ini berkaitan dalam hal penerimaan produk terhdap konsumen. Konsumen cenderung lebih tertarik pada produk yang memiliki tampilan fisik yang menarik, selain itu karena produk ini berupa produk hand sanitizer, konsumen juga akan mempertimbangkan aroma dari produk tersebut. Karena produk ini dibuat dengan bahan alam, maka hasil yang dihasilkan akan berbeda dengan produk yang telah ada di pasaran. Oleh karena itu, uji ini dilakukan untuk mengetahui sifat fisik dari produk yang dibuat. Berdasarkan hasil uji organoleptis terhadap sediaan Hand Smoothitizer, diketahui bahwa semua formulasi yang dibuat menunjukan hasil bahwa tidak ada perubahan bentuk, bau dan warna pada sediaan dalam rentang waktu 1 minggu. Data hasil uji organoleptis sediaan Hand Smoothitizer dapat dilihat pada tabel II berikut:

Tabel II. Hasil Uji Organoleptis

\begin{tabular}{cccc}
\hline Formula & \multicolumn{3}{c}{ Uji organoleptis } \\
\hline I & Bentuk & bau & warna \\
& Cair & $\begin{array}{c}\text { Aroma } \\
\text { lidah } \\
\text { buaya }\end{array}$ & cokelat \\
II & Cair & $\begin{array}{c}\text { Aroma } \\
\text { alkohol } \\
\text { Aroma } \\
\text { alkohol }\end{array}$ & cokelat \\
III & Cair & kekuningan \\
\hline
\end{tabular}

\subsection{Uji pH}

Uji pH dilakukan untuk mengetahui nilai $\mathrm{pH}$ dari sediaan Hand Smoothitizer. Nilai $\mathrm{pH}$ berkaitan dengan kejadian iritasi kulit yang mungkin akan ditimbulkan akibat pemakaian sediaan Hand Smoothitizer. Nilai $\mathrm{pH}$ yang terlalu asam atau basa dapat menyebabkan iritasi pada kulit. Nilai $\mathrm{pH}$ yang terlalu basa juga akan mengakibatkan rasa tidak nyaman saat pemakaian sediaan Hand Smoothitizer karena sifat basa dapat menyebabkan licin pada kulit. Berdasarkan hasil uji pH Uji pH terhadap sediaan Hand Smoothitizer, diketahui bahwa semua formulasi yang dibuat menunjukan nilai $\mathrm{pH}$ yang sesuai untuk sediaan topikal, standar $\mathrm{Ph}$ untuk sediaan topikal yaitu 5-7. Nilai $\mathrm{pH}$ pada FI : 6, FII : 7 dan FIII : 6. Data hasil uji pH sediaan Hand Smoothitizer dapat dilihat pada tabel III berikut :

Tabel III. Hasil Uji Ph

\begin{tabular}{cc}
\hline Formula & Ph \\
\hline I & 6 \\
II & 7 \\
III & 6
\end{tabular}

Uji pH dilakukan untuk melihat tingkat keasaman sediaan Hand Smoothitizer spray yang bertujuan untuk memastikan sediaan yang dihasilkan tidak mengiritasi kulit. Standar $\mathrm{pH}$ sediaan topikal yang memenuhi kriteria $\mathrm{pH}$ kulit yaitu 4,5-6,5. ${ }^{[14]}$ Berdasarkan data hasil uji pH diketahui bahwa FI dan FIII memenuhi kriteria nilai pH untuk sediaan topikal. 


\subsection{Uji Bobot Jenis}

Tujuan dari uji bobot jenis yaitu untuk mengetahui bobot jenis dari sediaan yang dibuat. Hasil uji bobot jenis sediaan Hand Smoothitizer dapat dilihat pada tabel IV berikut:

Tabel IV. Hasil uji bobot jenis

\begin{tabular}{cc}
\hline Formula & Bobot jenis \\
\hline I & $0,72 \mathrm{~g} / \mathrm{mL}$ \\
II & $0,73 \mathrm{~g} / \mathrm{mL}$ \\
III & $0,86 \mathrm{~g} / \mathrm{mL}$ \\
\hline
\end{tabular}

\subsection{Uji antibakteri sediaan Hand Smoothitizer terhadap bakteri $S$. aureus}

Uji aktivitas antibakteri bertujuan untuk mengetahui kemampuan sediaan dalam menghambat bakteri $S$. aureus. Uji aktivitas antibakteri dilakukan menggunakan media NA terhadap bakteri $S$. aureus. Uji aktivitas antibakteri juga bertujuan untuk mengetahui kemampuan ekstrak kulit jeruk nipis dan lidah buaya dalam menghambat pertumbuhan bakteri S. aureus. Konsentrasi diambil sebanyak 0,01\% untuk ekstrak kulit jeruk nipis, ekstrak lidah buaya, spray blank (gliserin+alkohol 70\%+metil paraben) dan spray aktif (ekstrak kulit jeruk nipis+ekstrak lidah buaya+gliserin+alkohol 70\%+metil paraben). Berdasarkan hasil uji aktivitas antibakteri, diketahui bahwa ekstrak kulit jeruk nipis, ekstrak lidah buaya dan spray blank dapat menghambat pertumbuhan bakteri S. Aureus. Zona hambat yang paling luas didapatkan dari spray aktif (ekstrak kulit jeruk nipis+ekstrak lidah buaya+gliserin+alkohol $70 \%+$ metil paraben), zona hambat yang didapat yaitu sebesar $10 \mathrm{~mm}$. Uji aktivitas antibakteri menunjukan, sediaan Hand smoothitizer mampu memberikan daya antibakteri terhadap bakteri S.aureus yang ditandai dengan adanya zona hambat pada media NA. Daya antibakteri disebabkan oleh adanya ekstrak kulit jeruk nipis yang memiliki efek menghambat pertumbuhan bakteri S.aureus. ${ }^{[15]}$ Selain itu, ekstrak lidah buaya juga memiliki sifat sebagai antibakteri terhadap bakteri gam positif dan negatif, termasuk S.aureus. ${ }^{[16]}$ Berdasarkan hasil uji aktivitas antibakteri, diketahui diameter zona hambat termasuk dalam kategori zona hambat sedang, yaitu sebesar $10 \mathrm{~mm}$. Berdasarkan zona hambatan aktivitas antibakteri digolongkan menjadi beberapa golongan yaitu, daerah zona hambat $<5 \mathrm{~mm}$ (lemah), daerah zona hambat 5$10 \mathrm{~mm}$ (sedang), zona hambat $10-20 \mathrm{~mm}$ (kuat) dan daerah zona hambat $>20 \mathrm{~mm}$ (sangat kuat). ${ }^{[17]}$

Berdasarkan Hasil, uji aktivitas antibakteri sediaan Hand Smoothitizer terhadap bakteri $S$. aureus dapat dilihat pada gambar 2 berikut :

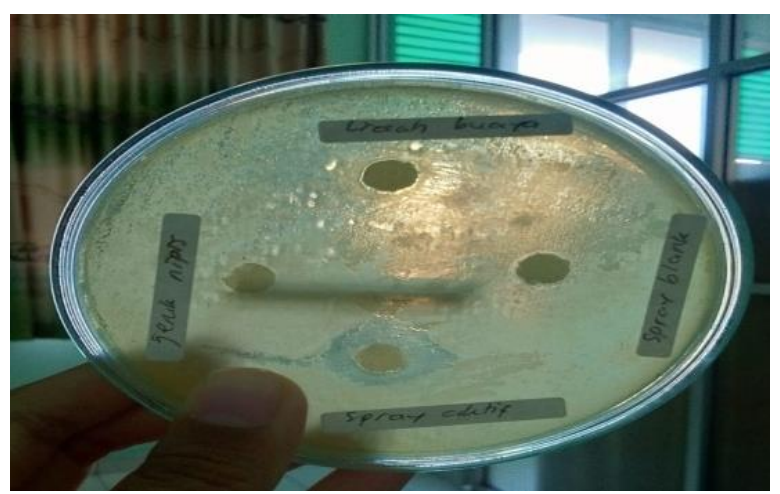

Gambar 2. Hasil Uji antibakteri sediaan Hand Smoothitizer terhadap bakteri S. aureus 


\section{KESIMPULAN}

Berdasarkan penelitian sediaan Hand Smoothitizer memiliki hasil evaluasi yang baik, yaitu meliputi hasil uji organoleptis yang menunjukan tidak adanya perubahan bentuk, bau dan warna pada sediaan dalam waktu 1 minggu. Hasil uji $\mathrm{pH}$ menunjukan bahwa ketiga formulasi memiliki nilai rentang $\mathrm{pH}$ yang sesuai dengan $\mathrm{pH}$ sediaan topikal yang memenuhi $\mathrm{pH}$ kulit yaitu, 4,5-6,5. Hasil uji kesukaan menunjukan bahwa FIII merupakan formula yang banyak disukai oleh responden. Hasil uji aktivitas antibakteri menunjukan bahwa sediaan Hand Smoothitizer menunjukan kemampuan dalam menghambat bakteri S.aureus.

\section{DAFTAR PUSTAKA}

${ }^{[1]}$ Husni, Amir. 2018. Pengendalian Mutu Hasil Perikanan. UGM Press : Yogyakarta.

${ }^{[2]}$ Riyadi, Alexander Lucas Slamet. 2016. Ilmu Kesehatan Masyarakat. Puslitbang Ekologi Kesehatan : Yogyakarta.

${ }^{[3]}$ Kemenkes RI.2017. Profil Kesehatan Indonesia Tahun 2016. Kemenkes RI: Jakarta.

${ }^{[4]}$ Freeman, MC., Stocks, ME., Cumming, O., Jeandron, A., Higgins, JP., Wolf,J., PrüssUstün, A., Bonjour, S., Hunter, PR., Fewtrell, L., Curtis V, 2014, Hygiene and health: systematic review of handwashing practices worldwide and update of health effects, Trop Med Int Health, 19(8):906-16.

[5] Patricia, Amelinda Diana. 2019. Uji Daya Antibakteri Gel Hand Sanitizer Minyak Atsiri Seledri (Apium gaveolens). 8 (1)

[7] Wardani, Resti Puspita. 2017. Pengaruh Ekstrak Etanol Kulit Jeruk Nipisb(Citrus aurantifolia (Christm.) Swingle) terhadap Penyembuhan Ulkus Traumatik pada Rattus norvegicus Strain Wistar. 1 (1)

${ }^{[6]}$ Jayani, Nikmatul Ikhrom Eka, Kartini, Nurul Basirah. 2017. Formulasi Sediaan Sabun Cuci Tangan Ekstrak Jeruk Nipis (Citrus aurantifolia) dan Efektivitasnya sebagai Antiseptik. 4 (3)

${ }^{[8]}$ Furnawanhi, I. 2007. Khasiat dan Manfaat Lidah Buaya si Tanaman Ajaib. Jakarta : Ago Media Pustaka.

[9] Agarry, O., O., Olayeye, M.T., Bello Michael, C.O., 2005. Comparative Antimicrobial Activities of Aloe Vera Gel anD Leaf. Biotechnology. 4 (2) 14-34.

${ }^{[10]}$ Hartanto, E.S. dan E.H. Lubis. 2002. Pengolahan Minuman Sari Lidah Buaya (Aloevera linn.). warta IHP/J. Ago-Based Industry.

[11] Sulistyani, Nunung., Eni Kurniati., Yakup dan Risa Ayu Cempaka. 2016. Aktivitas Antibakteri Infusa Daun Lidah Buaya (Aloe barbadensis Miller).

${ }^{[12]}$ Lawrence, R., Tripathi, P., Umar, E.J. (2009). Isolation, Purification and Evaluation of Antibacterial Agents from Aloe vera. Brazillian Journal of Microbiology, 40, 906-915.

[13] Balouiri, M. 2016. Methids for in Vitro Evaluating AntimicrobialActivity. Jurnal of Pharmaceutical Analysis. (6); 71-79

${ }^{[14]}$ Tranggono, L., 2007.,Buku Pegangan Ilmu Pengetahuan Kosmetik. Gamedia Pustaka Utama : Jakarta.

${ }^{115]}$ Lauma, Sartika Widia, dkk. 2014. Uji Efektivitas Air Perasan Jeruk Nipis(Citrus aurantifolia) terhadap Pertumbuhan Bakteri Staphylococcus aureus secara In Vitro. Vol $4(4)$

[16] Habeeb F, Shakir E, Bradbury F, Cameron P, Taravati MR, Drummond AJ, Gay Al and Ferro VA. 2007. Screening Methods used to Determine the Antimicrobial of Aloe vera inner gel. Methods, 42: 315-320. 
[17] Pradana, Dedi, dkk., 2013. Uji Daya Hambat Ekstrak Kulit Batang Rhizophora mucronata Terhadap Pertumbuhan Bakteri Aeromonas hydrophilia, Sterptococcus agalactiae dan Jamur saprolegnia sp, Secara In Vitro., Departemen biologi., Fakultas MIPA., Universitas Sumatera Utara., Medan: Indonesia.,20155. 